\title{
Survey of personality factors and impulsivity in active and non-active elderly men (2012)
}

\author{
Eskandarnejad $\mathrm{M}^{*}{ }^{1}$, dindar $\mathrm{H}^{2}$, mollaei $\mathrm{F}^{3}$
}

\begin{abstract}
Introduction and purpose: Different personality factors and impulsivity can directly affect life style and behaviors of older people. Therefore, the aim of this study was to compare impulsivity and personality factors in physically active elderly and sedentary individuals.

Materials and methods: This comparative correlational study used random stratified sampling method to recruit 90 elderly living at Tabriz city in 2012. Data were collected using five personality factors questionnaire (NEO) and Barrat impulsivity Scale. We used independent sample t-tests, ANOVA and Pearson correlation coefficient to analyze data using SPSS software version 19. Actual data analysis was conducted among only 80 participants (40 active and 40 non-active elders) who completely answered questionnaires.
\end{abstract}

Findings: Findings from the present study revealed a significant difference in openness personality $(\mathrm{p}=0.013)$ among active vs. sedentary elderly. There was a direct relationship between impulsivity and Neuroticism ( $\mathrm{r}=0.393, \mathrm{p}=0.02)$ while, there was a significant negative correlation between impulsivity and extraversion $(\mathrm{r}=-0.320, \mathrm{p}=0.013)$, agreeableness $(\mathrm{r}=-0.598, \mathrm{p}=0.001)$ and conscientiousness $(\mathrm{r}=-$ $0 / 684, p=0.01$ ). Besides, there was a positive significant association between impulsivity and lack of program elements $(r=0.272, p=0.037)$, cognitive impulsivity $(r=0.386, p=0.003)$. In contrast, series of negetaive significant correltion was reported between Neuroticism and extraversion $(r=-0.317, p=0.014)$ agreeableness $(\mathrm{r}=-0.447, \mathrm{p}=0.001)$ as well as conscientiousness $(\mathrm{r}=-0528, \mathrm{p}=0.001)$.

conclusion: There was no significant difference between subscales of impulsivity and personality factors (except openness) in active and inactive elderly men. However there was a relationship between impulsivity and some of personality factors which can be influenced by several factors, including physical activity.

Keywords: Personality Factors, Impulsivity, Active Elderly, Non-Active Elderly, Men

Received: 2015/12/27Ａccepted: 2016/09/10

Copyright (c) 2018 Quarterly Journal of Geriatric Nursing.This is an open-access article distributed under the terms of the Creative Commons Attribution international 4.0 International License(http://creativecommons.org/licenses/by /4.0/) which permits copy and redistribute the material, in any medium or format, provided the original work is properly cited.

1 - Associate Professor, Motor behavior and sport psychology department, physical education and sport science faculty, university of Tabriz, Tabriz, Iran. (Corresponding Author):E-mail: eskandarnejad@tabrizu.ac.ir 2 -MSc in Motor behavior and sport psychology, physical education and sport science faculty, university of Tabriz, Tabriz, Iran

3 - MSc in Motor behavior and sport psychology, physical education and sport science faculty, university of Tabriz, Tabriz, Iran 


\section{بررسى عوامل شخصيتى و تكانشكَرى در مردان سالمند فعال و غير فعال شهر تبريز در سال (qז|}

مهتا اسكندرنزاد" ؛ حميده ديندار '، فريبا ملائى

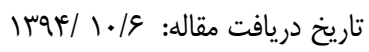

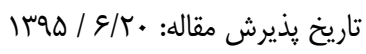

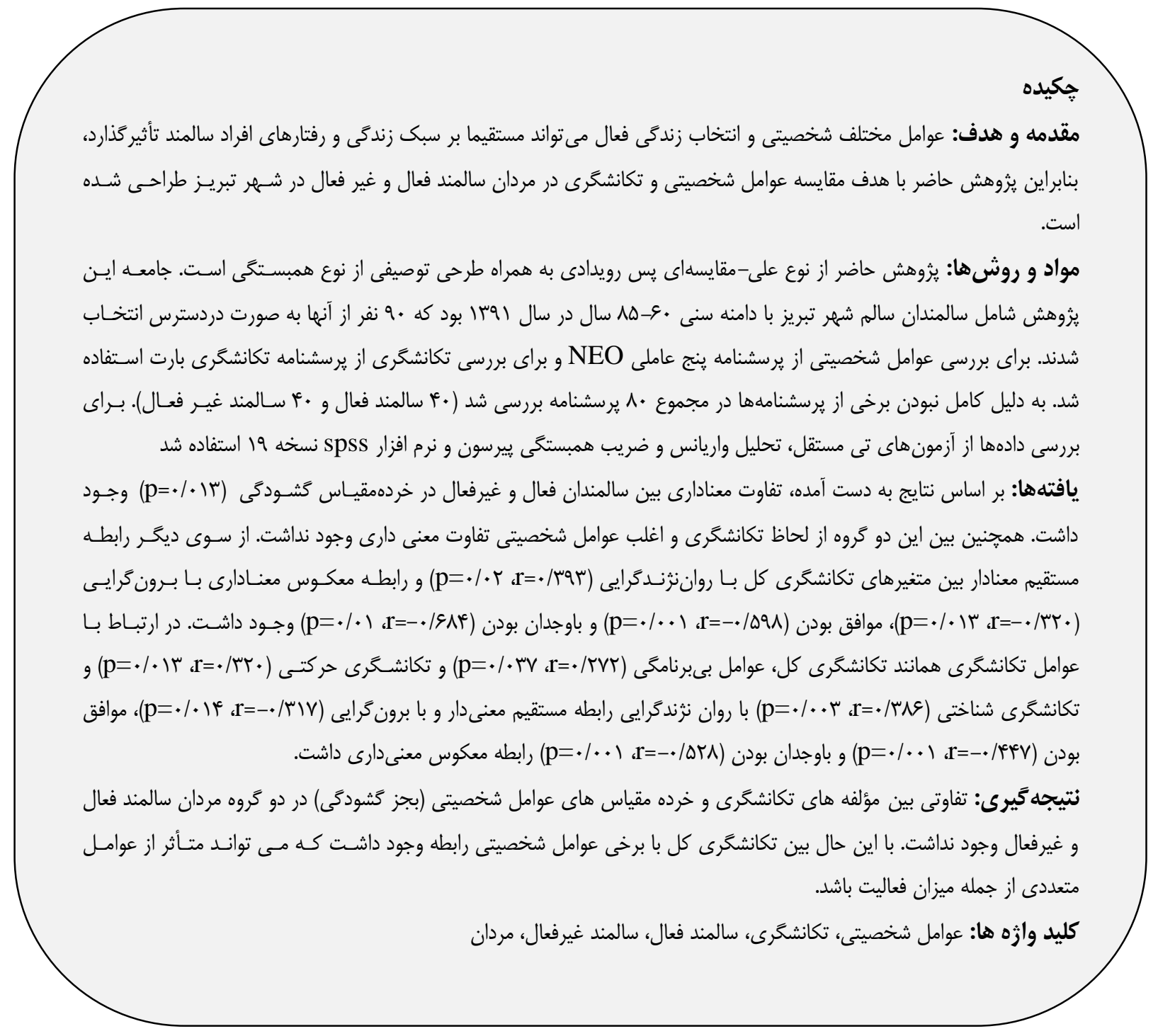

ا- دانشيار گروه رفتارحر كتى و روانشناسى ورزشى دانشكده تربيت بدنى و علوم ورزشى، دانشگاه تبريز، ايران (نويسنده مسؤول). يست الكترونيكى: m.eskandarnejad@tabrizu.ac.ir

r- دانشجوى كارشناسى ارشد رفتارحركتى دانشكده تربيت بدنى و علوم ورزشى، دانشكاه تبريز، ايران بـ دانشجوى كارشناسى ارشد روانشناسى ورزشى دانشكده تربيت بدنى و علوم ورزشى، دانشعاه تبريز، ايران 
مجموعه عوامل مختلف ناشى مى گردد، كه از مهمترين اين عوامل عدم فعاليت و كم تحركى و عدم استفاده صحيح از عضلات اسـت كه ممكن است ريشه در سالهاى خذشته و مراحل قبلى زنـدكى داشته باشد [ب]. اين در حالى است كه فعاليت بدنى اثر جوانسازى بر جسم و روان داشته باشد و بـه سـالهـاى عمـر سـالخوردكان؛ جوانى مجدد مىبخشد و ظرفيـت سـالمندان را بـراى قبـول يـى

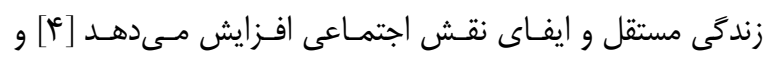
سالمندان با جايغزين كردن فعاليتهايى متناسب با سن خود مسىتوانند خلاهاى موجود در زندگى خود را ير نموده و تأثير بهسـزايى در وضعيت روانى و ويزگگهاى رفتارى آنها داشته باشند.

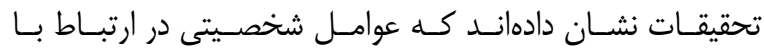
تكانشگُى هستند. بسيارى از افراد در زندگى روزمره خـود دسـت

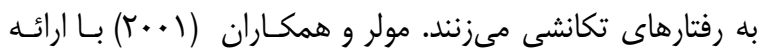
يك ديدكاه جامع تحت عنوان رويكرد زيستى- روانى - اجتمـاعى، تكانشكَى را به عنوان برخوردارى از يك استعداد قبلى در راستاى انجام واكنشهاى سريع و برنامهريزى نشده به تحريكات درونى و بيرونى بدون درنظر كرفتن يِيامدهاى منفى اين رفتارها براى خـود و ديخران، تعريف مى كنند [ه]. تكانشخَرى طيفى گسترده از رفتـار هايى است كه روى آن كمتر تفكر شده و به صورت رشــ نايافتـهـ براى دستيابى به يك ياداش يا لذت بروز مى كند و عموماً همـراه با درجات خطر بالا هستند. اين رفتارها سـريع، ناخواسـته و بــدون فكر و مستعد اشتباه مىباشند كه مسىتـوان آنهـا را از جنبـهــاى مختلف مورد ارزيابى قرار داد. تكانشكرى از ديدگاه رفتارشناسى در

4- Moeller et al
در جامعه امروز سالمندان جزء گروههاى بزرى اجتماع بـه حسـاب مى آيند و سالمندى سرنوشتى اجتناب نايذير است. براساس بـرآورد و اعلام سازمان بهداشت جهانى ييشبينى مى شود تـا سـال .r.r. طول عمر به WV سال برسد و جمعيت بالاى •و سال، •r در صد جمعيت جهان را در بر خواهند گرفت. در ايران نيـز براسـاس سـر شمارى نفوس و مسكن، جمعيـت سـالمندان از هـ درصــ در سـال

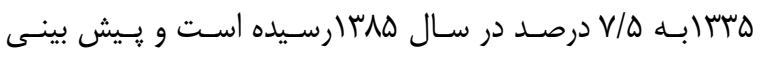
مى شود در سال •أأ| در كشور ما انفجـار جمعيـت سـالمندى رخ دهد [1]. در واقع جهان در سايه ييشرفتهاى علمى شاهد افزايش جمعيت سالمندان است، از طـرف ديخـر سـالمندان شـاهد تقليـل توانايىهاى جسمى و روانى خويش هسـتند و انـواع بيمـارى هـا و مشكلات روانى آنها را تهلديد مى كند. به عقيده اريكسون'، سالمند بايد بحران كمال و ناميدى را حل كند و بـه نظـر ييـى (عد19) ييرى با زير سوال بردن مواردى همراه اسـت از جملـه جسـتجوى زمينه هاى ديگر يا در حسرت شغل قبلى، اسـتفاده از زنــدى يـا تسليهم در برابر دردهاى جسمى، مبارزه با مركى يا تسـليم در برابـر آن. هر هُند كه اكثر سالمندان، از نظرشخصيت و خويشتن پِندارى تغييرات ناگُهانى خشمخير يِيدا نمى كنند، در ارتباط با يِيرى مى توان جهار نوع شخصيت تشـخيص داد، يكيارجهـ، ضدضـربه، منفعـل-

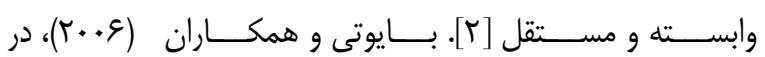
يزوهش هاى خود بر روى سالمندان بر اين امر تاكيد كردهانــ كـهـ ناتوانىها و از كار افتادگىهاى شايع در دوران سالخوردگى از

\section{Erickson} 2 pik

3 Payne et al 
مى كنند و با يول قرض كردن يا خريد اقساطى براى خـود از نظـر مالى مشكل ايجاد مى كنند [ [11].

در محيطهاى مختلف ورزشى نيز كه نيازهـاى برخى از تكـاليف، ورزشكار را ملزم به اتخاذ تصميمات سريع در جهت واكنش به اين نيازها مى كند سازمى تكانشكَى ديده مىشود. اين احتمال وجود دارد كه تكانشكَرى نقش مثبتى را در رفتار حركتى در موقعيــهاى خاص داشته باشـــ [TI]. بـدين صـورت كـه ممكـن اسـت موقعيت هايى به وجود آيد كه محدوديت زمـان در دسـتيابى بـهـ

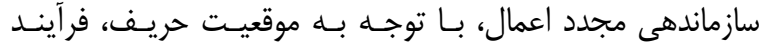
تصميم كيرى و سازماندهى سيستم حركتى بـراى جلـوكيرى از پاسخ وجود داشته باشد در هنين وضعيتى به نظر مىرسـد برخى درجات تكانشكَى به ورزشكار در دستيابى به اهداف خود كمى مى كند. تبيين اين فرضيه ممكن است براساس مفاهيم عملكردى

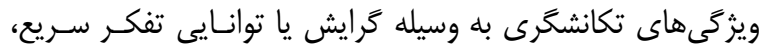
عمل و صحبت كردن تند صورت گيرد [سرا]؛ شواهد متعددى تأثير تكانشخَى را بر كنترل حركات تأييد كـرده انـد و نشـان دادهانــــ عاملهاى تكانشكرى نقش مؤثرى در تصـميهميـرى دارنـــــ[ [II].

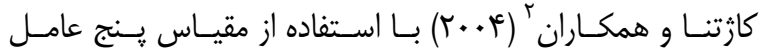
شخصيت، شخصيت را بـين ورزشـكاران رشـته هـاى ورزشـى بـا ريسك بالا بررسى كردند و نتيجه كَرفتند ورزشـكاران بـا ريسك زياد در عامل ثبات احساسات نمرههاى بيشترى و در وظيفهشناسى و كَشودى نمره كمتـرى در مقايسـهـ بـا ورزشـكاران رشـتهــاى ورزشى با ريسك پـايين كسـب كردنــ [10]. همجنـين بشـارت و همكاران (זوسا) در بررسى ورزشـكاران رشـتهــاى برخـوردى و

2 Kajtna et al

بركيرنده سود كوتاه مدت هر خند كمارزش در برابـر دسـتاوردهاى بلندمدت ولى با ارزش مىباشد [9]. افراد بر اساس شيوه عمـل و تفكر در موقعيتهاى مختلف با هم تفاوت دارند. فراينـد تصـميم-

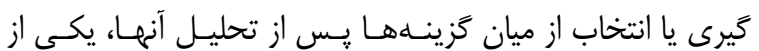
عالى ترين يردازشهاى شناختى به شـمار مـىآيــ. تصـميمثيـرى مخاطره آميز اهميت بالايى در زندكى فردى و اجتماعى افراد دارد و اختلال در اين نوع تصميمَّيرى هسته اصلى يديده تكانشخرى و رفتارهاى تكانشى را تشكيل مىدهد [V]]. همان طـور كـه خـردهمقياسهاى آزمـون بـارت ' نشـان مـىدهــد، تكانشـحرى عناصـر مختلفى دارد. سه طبقه در تكانشخَرى معين شــه اسـت: حركتى (عمل بدون فكر)، شناختى/توجهى ( فقدان تمركز روى تكليف دم دستى)، و بىبرنامكَى (تمركز روى ارائه بدون حساب نتايج آينـده) [^]. از ديدكًاه روانشناختى سه مقوله كاهش حساسيت نسـبت بـــ

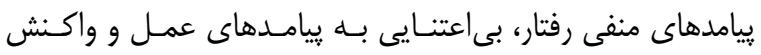
سريع يِيش از ارزيابى كامل اطلاعـات، در تعريـف رفتـار تكانشـى كنجانده شده و اين سازه بر بايه مفاهيم تنبيه (خاموشى)، گـزينش پاداش و بازدارى ياسخ (توجه) مورد بررسى قرار گرفتـه اسـت [9]. يكى از ارتباطاتى كه تكانشگرى با عوامل شخصيتى دارد مى توان به عامل خشونت اشاره كرد. در واقع تكانشـحَى باعـث خشـونت فردى نمى شود ولى شيوه خشونت را تحت تأثير قرار مىدهد. افراد تكانشكر لزوما يرخاشـحَرتر از افـراد غيـر تكانشـحر نيسـتند [•l]. تكانشكَرى حركتى (عمل بدون تصميم قبلى) مشكلتر از بقيه بــــ نظر مىرسد. كسانى كه در خرده مقياس حركتى نمره بـالا مسىگيرند كارها را ناتمام رها مى كنند ولى عصـبانى هسـتند، يرخـاش

\section{Barrat}


قرار گَيرد. تغييرات دوران سالمندى تأثيرات عميقى بـر زنـدَى و

بهداشت روانى او دارد. اگر شخصيت فرد انعطاف يذير باشد توانايى

سازكًارى با اين تغييرات بيشتر خواهدبود. در اين ميان اخر سـالمند

اين تغييرات را در جهت منفى ادراك كنند ميزان انعطاف يذيرى و

سازكارى يايين خواهد آمد. ويزَّى هاى شخصيتى فرد مستوانـد او

را منزوى و تنها كند. ترايودى و همكاران (F( +r) به بررسى برخى ويزَى هاى سالمندان با تكانشعَرى يرداختند و مشاهده كردند كـهـ

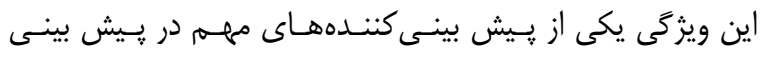
خودكشى سالمندان مىباشد [19]. همانطور كه در بـالا بيـان شـــ نتايج برخى از تحقيقات نشان داده است فعاليت بدنى، موجب بروز ثبات (يايدارى) شخصيت، رشد اجتماعى و اعتماد به نفس بيشتر و اضطراب و افسردگى كمتر در افراد مسى كـردد، همجنـين مـى

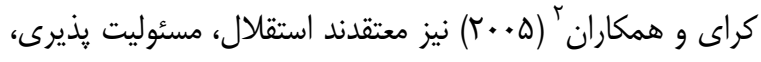
آينده نكخرى، روحيه جمعى، كسـب هويـت، يـذيرش اجتمـاعى و عزت نفس از مفاهيم و مؤلفههاى ويزگكىهاى شخصيتى هسـتند كه از طريق فعاليت بدنى و مشاركت ورزشى در سالمندان تقويت مى شوند [·r]. براين اساس و با توجه به ضرورت كار بر ويزَّىهاى افراد سـالمند و بررسـى مفهـوم تكانشـخرى و ارتبـاط آن بـاــا عوامل شخصيتى در افراد سالمند كه مستقيماً بر سـبك زنـدگى و

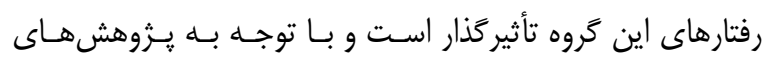
محدود در حيطه سالمندى و مقايسه اين دو ويزَّى در سـالمندان فعال و غير فعال، مقاله حاضر به دنبـال يـافتن جـواب بـــاى ايـن موضوع مهم مىباشد.

غيربرخوردى مشاهده نمودند كه در خرده مقيـاسهـاى شــاختى، حركتى و بىبرنامكى تكانشكَرى ورزشكاران رشتهاى برخـوردى نسبت به كروه مقابـل از مقـادير بيشـترى برخـوردار بودنـــ [II]]. همجنين كلخوران (•وسا) در يـروهش خـود نشـان داد كـه بـين ورزشكاران و غير ورزشكاران در صفات شخصيتى عوامل گشودگى و وظيفه شناسى تفاوت معنادارى وجود دارد ولى درعامل شخصيت سازكارى تفاوت معنـادارى وجـود نــدارد [19]. فييـو و همكــاران'

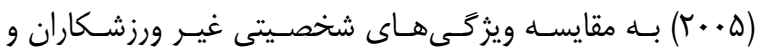

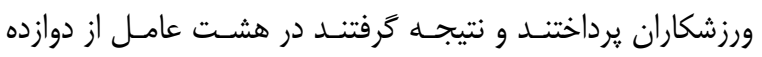
عامل مـورد بررسـى (بـازدارى، كـج خلقى، تجـاوز كـارى، بـىحوصلكى،دادخواهى، دلوايس سـلامت بـودن، ركَّويى و تهيـيج يذيرى)، اختلاف معنادارى بين دو گروه ورزشكار و غيـر ورزشـار وجـود دارد [IV]. فعاليـت بـدنى باعـث بهبـود انعطـاف يـذيرى و تحرك، عملكرد شناختى، سازگارى روانى و عملكردى مى شود كه

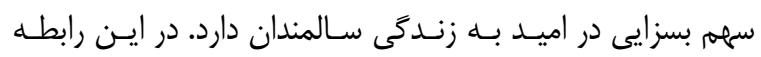
يروهشكَران درمطالعات خود به اين نتيجه رسـيدهانـد كـه فعاليـت بدنى سبب انسجام بيشتر صفات شخصيتى سـالمندان مسىشـود و معتقد هستند فعاليت مستمر باعث تقويت ويزخى هـاى شخصـيتى افراد از دوران كودكى تا سالمندى مىشود [11]. دوران سالمندى داراى برخى ويزگَى هـاى جسـمى، اجتمـاعى و روانى است كه مىتوان به كاهش نسبى قواى جسمى، بازنشستخى و دور شدن از موقعيتهاى شغلى كذشته و در نتيجـهـ تنهـيى و از دست دادن دوستان و نزديكان اشاره كـرد. ايجـاد شـرايطى بـراى طولانى كردن فعاليت هاى موثر، زندگَى مستقل بايد در مورد توجه

1 Fiho et al 
ابزار اندازَيرى يزوهش:

مقياس شخصيتى NEo-FFI: اين يرسشنامه شـامل •و سـوال است كه بر اساس تحليل عاملى نمرات فرم بلند آن به دست آمده

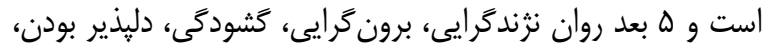
باوجدان بودن را اندازهيرى مى كند. افراد بر اساس مقياس ليكرت ه تايى نظر خود را در مورد هر سوال بيان مسى كنــــــــــــ از عوامل r| سوال مقياس را يوشش مىدهند. در كل آزمودنى در هر مقياس نمرهاى از صفر تا ئ كسب مى كند. كاسـتا و مــ كـىى (1999) ضريب آلفاى كرونباخ را بين \&1/ •تا عی/• كزارش كردند. كروسى (•^با() اين يرسشنامه را در ايران هنجاريابى كرد و روايى

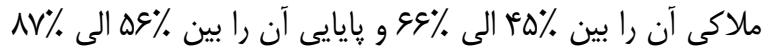
كزارش كرده است [اr]]. اين برسشنامه در نمونه سالمندان توسـط

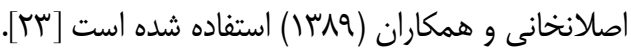

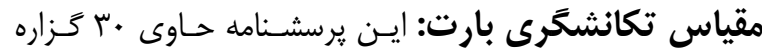
است و قابليت سنجش تكانشكَرى شناختى، حركتى و بىبرنـامكى را داراست. در مقياس بارت آزمودنى بر اساس مقيـاس ليكـرت ه كزينه اي نظر خود راد در مورد هر سوال بيان ميكند. حـداقل نمـره

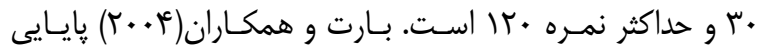
حدود |^/• براى نمرهى كل بدست آوردند. اختيـارى و همكـاران (IrAV) مواد اجرا كردند كه در كروه افـراد سـالم ضـريب آلفـاى كرونبـاخ

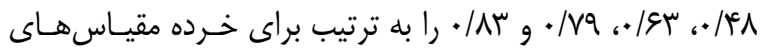
بعبرنامه گَى، حركتى، شـناختى و نمـره ى كـل گَزارش دادنـــ. مقياس يكى ابزار خود زَارشى اســـ و بــهـ بررسـى مؤلفـه هـاى شخصـيتى و رفتـارى تكانشـحَرى مـى هـردازد. ايـن يرسشـنامه

\section{روش يزوهش}

يزوهش حاضر از نوع على -مقايسـه اى يـسرويــادى بــه همـراه طرحى توصيفى از نوع همبستخى مىباشد. از ميان سالمندان شهر تبريز و به روش نمونهَيرى دردسترس (با توجه به تعداد جامعه در دسترس گروه فعال كه در ياركهــا حضـور مسىيافتــد)، •9 مـرد سالمند نمونه اين يزوهش را تشكيل مىدادند كه بـهـ دليـل كامـل يرنشدن يرسشنامهها توسط نمونهها، • إيرسشنامه از روند بررسى خارج شده و اطلاعات •^ سالمند در تحليل باقى ماند. با توجه بـــ افراد مراجعه كننده كه در ڤاركها و اماكن عمومى، بازارها، مساجد، مغازهها حضور داشتند، دامنـهى سـنى افـراد، •9 سـال (براسـاس ديدكاههاى رشد حركتى كه سـالمندى را بـالاى •ع سـال تعريـف نموده اند) الى هـ سال (عدم دسترسى به دامنه سنى بـالاتر) بـود. براسـاس توانـايى و سـابقه شـركت در فعاليـت بــنى و ورزش در يزوهش حاضر در دو گروه فعال و غيرفعال حضور يافتــد. افـرادى در گروه فعال قرار گرفتند كه به مدت دو سال ، سه روز در هفته و حداقل يك ساعت در روز در پاركها فعاليت ييـادهروى داشـتند. يس از كسب رضايت از افراد سالمند و اطمينان آنها به منظور حفظ اطلاعات شخصىى، برسشـنامهــاى اطلاعـات فـردى و مقيـاس شخصيتى NEO و تكانشكَرى بارت را تكميل نمودند. بـه منظـور تعيـين طبيعسى بــودن توزيـع داده هــا از آزمـون كلمـوخروف اسميرنوف استفاده شد. بـا توجـهـ بــه بيشـتر بـودن مقــادير سـطح معنادارى آزمون از مقدار هـ/•، براى مقايسه خــده مقيـاسهـاى تكانشخَرى و شخصيت در دو حَروه از آزمونهـاى پارامتريـك تسى مستقل، تحليل واريانس و به منظور تعيين ارتباط بـين متغيرهـا از ضريب همبستخى ييرسون استفاده گرديد. 


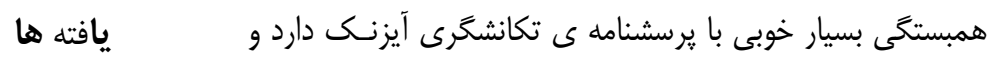

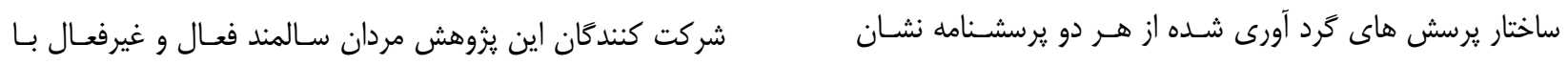

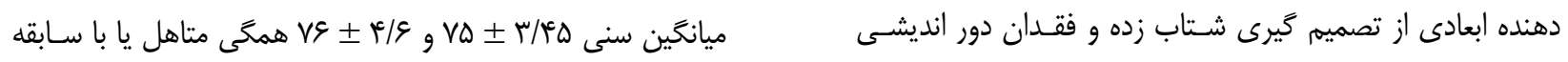

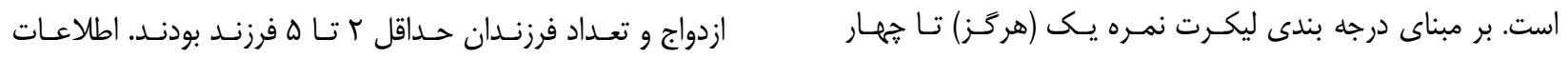

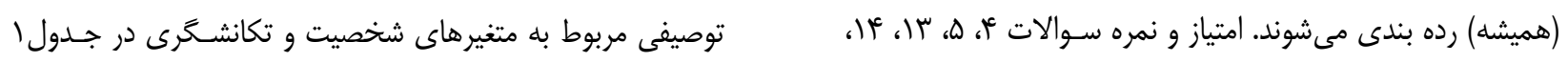

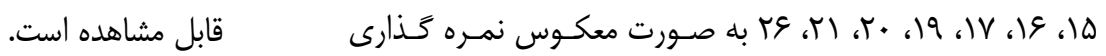
مىشوند [rT].

جدول ا. متغيرهاى شخصيت و تكانشكرى در دو تروه

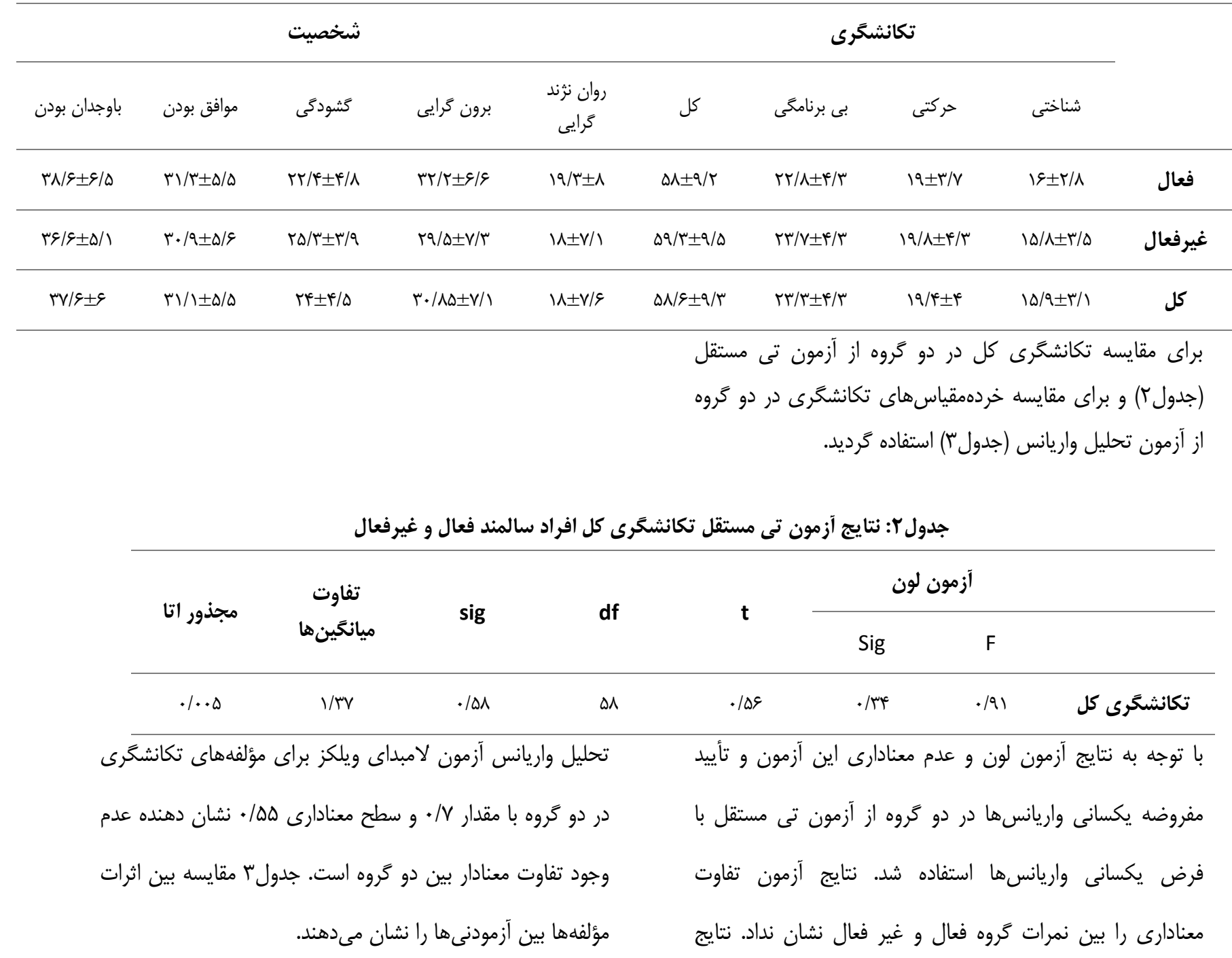




\section{جدول ": نتايج آزمون تحليل واريانس مؤلفههاى تكانشَّرى افراد سالمند فعال و غيرفعال}

\begin{tabular}{|c|c|c|c|c|c|c|c|}
\hline مجذور آتا & سطح معنى & $\mathbf{F}$ & مربعانتين & درجات آزادى & مربعات & متغيير وابسته & منبع تغيير \\
\hline .1 .14 & $\cdot 14 \cdot 9$ &.$|99|$ & $\mid r / \cdot r g$ & 1 & $\mid w / \cdot r$ & مؤلفه بى برنامهكى & \\
\hline $.1 . .9$ &.$/ 4 \mathrm{~V}$. & $\cdot / \Delta \Gamma$. & $N \mid q 4$ & 1 & $N / 941$ & مؤلفه تكانشكرى حركتى & 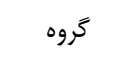 \\
\hline . & . $/ \& \wedge \Delta$ &.$/ 19 \mathrm{~V}$ & $1 / 9 V r$ & 1 & $1 / 9 \mathrm{Vr}$ & مؤلفه تكانشكرى شناختى & \\
\hline
\end{tabular}

سالمندان فعال و سالمندان غيرفعال وجود نداشت. براى بررسى با توجه به اطلاعات جدول و سطح معنىدارى آزمون عوامل شخصيت در سالمندان فعال و غيرفعال نيز از آزمون تحليل p p \0/05) از نظر آمارى تفاوت معنادارى بين خردممقياسهاى

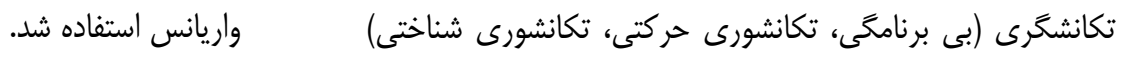

جدول ع: نتايج آزمون تحليل واريانس مؤلفههاى تيبهاى شخصيتى افراد سالمند فعال و غيرفعال

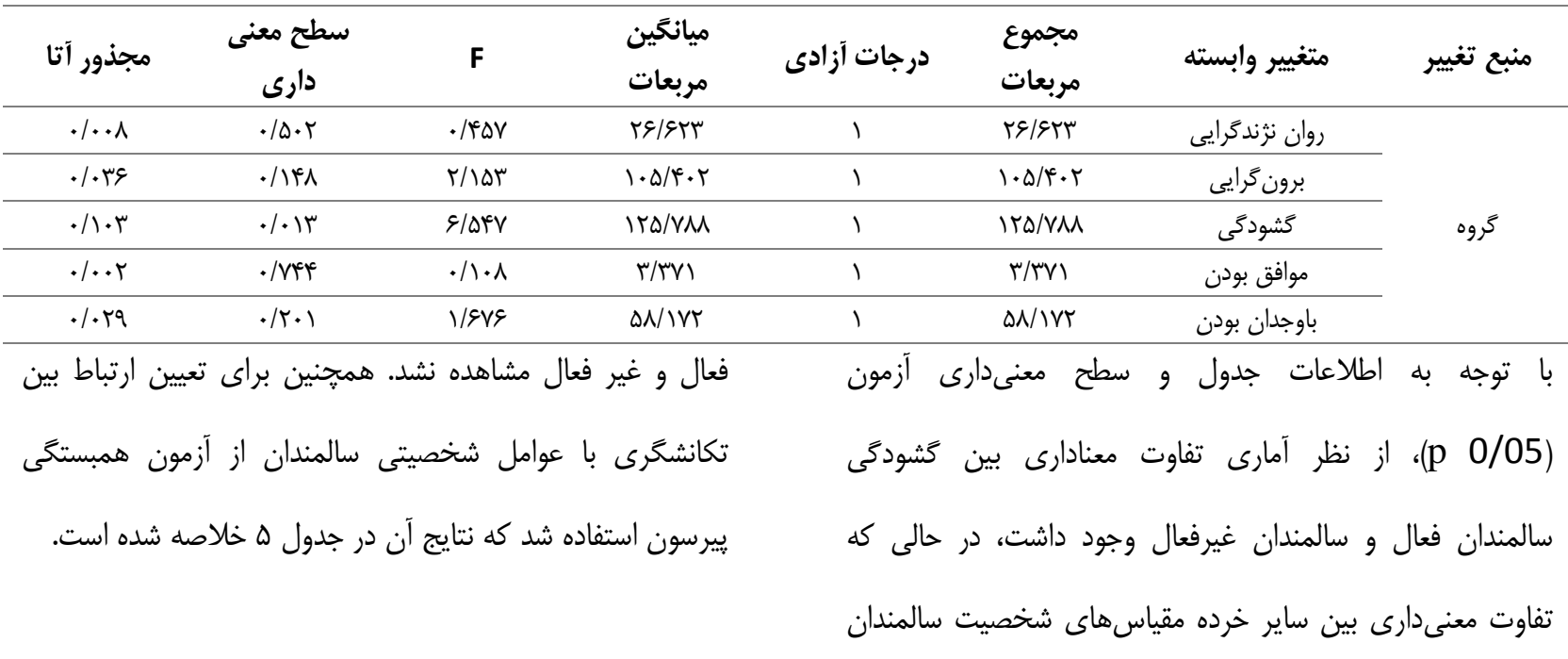

جدول ه: يافتههاى حاصل از آزمون ضريب همبستكى ييرسون در تعيين ارتباط بين تكانشكَى و شخصيت

\begin{tabular}{|c|c|c|c|c|c|c|}
\hline با وجدان بودن & موافق بودن & تششودتى & برونَّرايى & روان نزندترايى & & \\
\hline$-\cdot / \Delta \Lambda^{* * *=}$ & $-\cdot / 4 F V^{* * *}$ &.$- / \cdot r \Delta$ & $-\cdot / \mu \mid V^{*}$ &.$/ T Y Y^{*}$ & r & بى برنامكَى \\
\hline $.1 \ldots$ & $.1 \cdot .1$ & $\cdot / \Lambda \Delta \mid$ &.$/ .14$ & . $/ . r v$ & Sig & \\
\hline 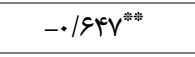 & $-\cdot / \Delta \omega \gamma^{* * *}$ & -.1 .49 &.$- / 419^{*}$ & . & r & تكانشكَى حركتى \\
\hline.$/ \cdots$ & $.1 \cdot .1$ &.$/ V T V$ & .1 .14 & r & Sig & \\
\hline.$- / \mathrm{C}^{\mathrm{V}} \mathrm{N}^{* * *}$ &.$-|F \Delta|^{* * * 4}$ & .11 .9 & $-\cdot / 1 \cdot v$ & 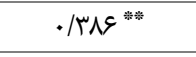 & $r$ & تكانشكَرى شناختى \\
\hline.$/ \cdots$ & $.1 \cdot .1$ &.$/ 41$. &.$|4 T|$ & 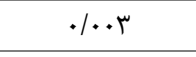 & Sig & \\
\hline.$- \mid 9 \wedge F^{* * *}$ & $-.109 \Lambda^{* * *}$ & $\% \cdots$ & $-\cdot / r^{* * * *}$ &.$/ \% q \Psi^{* * * *}$ & $r$ & تكانشخَرى كل \\
\hline$+1++$ & $.1 \ldots$ &.$/ 999$ & 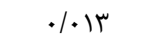 &..$+ r$ & Sig & \\
\hline
\end{tabular}

باوجدان بودن رابطه معكوس معنى دارى دارد و با گشودگى رابطـهـ.

معنى دارى ندارد. همجنين نتايج آزمون نشان داد كه هر سه مؤلفـه
با توجه به اطلاعات جدوله، تكانشخرى كـل بـا روان نزنـدرًايى رابطه مستقيم معنى دار داشته و بـا بـرون كرايسى، موافـق بـودن و 
مؤلفه تكانشخَرى شناختى با موافق بودن و باوجدان بـودن رابطـهـ

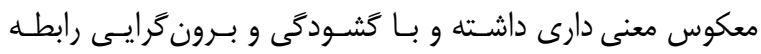

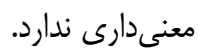

بعبرنامگى، تكانشخرى حركتى و شناختى با رواننزندًرايى رابطه مستقيم معنى دارى دارنــــ و دو مؤلفـهـ بــبرنـامكى و تكانشـحرى حركتى با برون گرايى، موافق بودن و باوجدان بودن رابطه معكوس معنى دارى داشته و با گشودگى رابطه معنى دارى ندارنـد. همجنـين

\section{بحث و نتيجلَيرى}

بيان كـرد كـه فعاليـت بـدنى و ورزش بـا تقويـت ويزخَى هـاى شخصيتى نظير عزت نفس، برون كرايى و خودكارآمدى و افزايش توانمندى هاى ارتباطى، منجر به تقويت ويزگى هـاى شخصـيتى

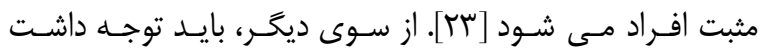
تكانشخرى، تمايل به عملى بدون تفكر مناسب و بدون توجـه بـهـ نتايج آن مىباشد، اين رفتارها سريع، ناخواسته، بدون فكر و مستعد اشتباه مىباشند و تحقيقات رابطه تكانشگرى را با نشانههاى خلقى و شخصيتى مورد بررسى قـرار داده و نشـان دادنــــــــالمندانى بـاــا

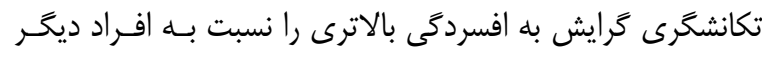
دارند [عץ] در تحقيق حاضر ابعاد تكانشكَرى با اغلـب مولفـههـاى شخصيت ارتباط بالا و معنى دارى را نشان داده است و بايد توجـهـ داشت به جز بعد رواننثندى با بقيه ابعاد ارتباط بالا و منفى دارنـد. در مدل پينج عاملى شخصيت روان رنجورى بر ويزگى هـاى منفى مثل غمه، ترس، خشه؛ برونگَرايى بر هيجان و تحرك؛ كَشودگى به تصـورات فعـال و توجـهـ بــه تجربـهـــاى عـاطفى؛ موافق بـودن بركرايش هاى فردى و همدردى با ديخران و نهايتاً باوجدان بـودن به كنترل تكانهها و بكارگيرى و داشتن طرح و برنامه دلالـت دارد [11]. نكته حائز اهميتى كه بايــد در ارتبــاط بـا عـدم معنى دارى تفاوت بين دوگروه مورد توجه قرار داد و شـايد علـت غيـر همسـو
نتايج يزوهش در رابطه با تكانشحَرى نيز نشان داد ميانخَين نمرات تكانشخَرى سالمندان فعال با غيرفعال باوجود برترى اغلب نمـرات براى گروه فعال تفــاوت معنـادارى وجـود نداشـت. اصـلانخانى و

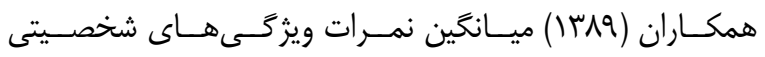
برونكَرايى، وظيفه شناسى، گَشودگى به تجربه و سازش يافتكى را

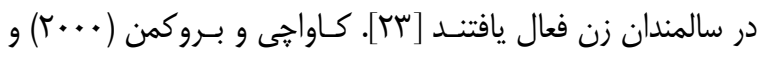
بايوتى (ع.+r) به اين نتيجه رسـيدند كـه سـطح بـالاى آمـادگى جسمانى، اضطراب را كاهش، يرخاشخَرى را تعـديل، برونخرايسى را

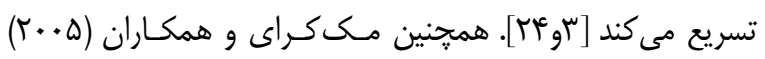

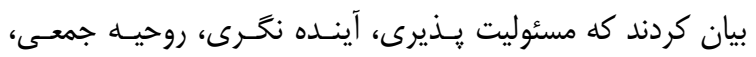
كسب هويت، پذيرش اجتماعى و عزت نفس از مفـاهيم و مؤلفـه هاى ويزگى هاى شخصيتى هستند كه از طريـق فعاليـت بـدنى و مشاركت ورزشى در سـالمندان تقويـت مسىشـوند [•r]. عبـدلى و همكاران (MMII) نيز به اين نتيجه رسـيدند كـه ميـانگَين نمـرات سالمندان فعال در برونگرايى و با ثباتى بالاتر از سالمندان غيرفعال بود [ع]. به عقيده مك آولى و همكاران نيز يـرداختن بـه فعاليـت بدنى مى تواند در تقويـت مؤلفههــاى شخصـيتى بـرون گرايسى، مقبوليت اجتماعى، عزت نفس و كاهش مؤلفه نوروتيسم در زنسان سالمند مؤثر باشد [؟ه]. بر اساس تحقيقات انجام شده، مىتوان 
مؤثرى به حل مسأله خود ببردازند. از اين رو مىتوان استنباط كرد كه سالمندان در طى عمر با فعاليت بدنى و مشاركت جسمانى مىتوانند تا حدودى تعارضات شخصـيتى خـود را كـاهش داده و بـــــ وضعيت مطلوبترى دست يابند [•ـ]. ايـن توانـايى نتيجـــ رشــــ طبيعى تبحرى است كه فرد در تمام مراحل قبلى كسب كرده است و تحت تأثير خانواده، مدرسه، پِايخـاهــاى اجتمـاعى اقتصـادى و فعاليت بدنى قرار مى گيرد [ آس]. با توجه به نتايج تحقيقات يِيشين و نتايج يزوهش حاضر مشخص مى شود كـه ويزگكى هـا و صـفات مختلف روانشناختى و جسمانى زيربنـاى رفتـارى فـرد را تشـكيل مىدهند. ارتباط بالاى ويثگى تكانشـخَى و جنبـهــاى مختلـف شخصيت در سالمندان با توجه به كمبود مطالعـات و بررسىهـاى مختلف در اين زمينه و اين محدوده سنى قابل توجـه اسـت. بايــــ توجه داشت كه با وجود عدم وجود تفاوت معنــادار بـين صـفات دو كروه فعال و غيرفعال (كه شايد ناشى از نوع مشـاركت در فعاليـت بدنى نمونهها باشد)، تحقيقات مختلـف نشـان دادهانـد كـه ميـزان فعاليت بدنى منظه با مدت زمان مشاركت ورزشى مىتواند تفـاوت معنى دارى در عوامل شخصيتى و سلامت و كيفيت زندگى در بين سالمندان فعال و غير فعال ايجاد كند [اس]]. به هرحال محدوديتهاى اين مطالعه كه افراد فعال از بـين سـالمندان بـا ييشكسـوتى ورزشى انتخاب نشدهاند و افرادى بودند كه زندگى فعـالى را بـراى خود انتخاب نموده بودند بنابراين ييشنهاد مىشـود ايـن مقايسـهـ و بررسـى بـر روى سـالمندان ورزشـكار ييشكسـوت در مقايسـهـ بـاــا غيروززشكاران انجام گيرد تا به نكات مـبهاه بـاقى مانــده در ايـن بررسى ياسخ داده شود. در آخر ييشـنهاد مسىشـود يـزوهشهـاى مشابه بر روى گروههاى سـنى ديخـر در مقايسـه بـا سـالمندان و
بودن نتايج اين يزوهش با نتايج برخـى از يـزوهش هـاى ييشـين باشد كه به انتخاب نوع نمونه ها در جامعهى سالمندان فعـال ايـن

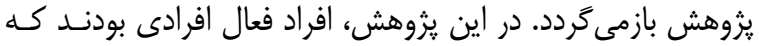
فعاليت آنها به بيادمروى و فعاليتهاى تفريحى محدود مىشـد، در حالى كه سالمندان فعال يزوهشهاى ديگر از سطح آمادگى بسـيار بالايى برخوردار بودند و در فعاليتهاى ورزشى و كروهـى شـركت داشتند. همجنين در تبيين يافتههاى اين يزوهش مىتوان كفت كه كَترهى رفتارهاى تكانشى متنوع است و نبايد نقش فرهنگ را در تعريف اين رفتارها ناديده گرفت. [TV]. در موضوعات تكانشكَرى و شخصيت تحقيقات مختلفى در ايران و جهان انجام شده است اما در ارتباط بـين ايـن دو مؤلفـه بـويثه در دوران سالمندى يزوهشى يافت نشد. بايد توجـهـ داشـت رفتارهـاى تكانشى گَستره بزرگى داشته و نبايد عوامل مختلفى مثل شخصيت و ويزگَىهاى جسمانى را ناديده انكاشت. در قـوىتـرين رابطـهـ در بين קنج عامل با تكانشكَرى به عامل باوجدانبودن و برونگرايسى مربوط مىشود. بايد توجه داشت افراد با عامل شخصيتى با وجدان بالا، خود نظهدهى و ييشرفت گرايى بالا دارند، تكانهاى عمل نمىكنند، برناملريزى قبل از عمـل را تـرجيح مـىدهنـــ و عمومـاً بــــ عادتهاى معمول ساختار يافته تمايل نشان مــدهنــــــــ بايـد توجه داشت افرادى بـا نمـرات تكانشـى شــاختى بـالاتر توانـايى كمترى به تحمل مشكلات شناختى داشته و افراد تكانشكر حركتى تمايل به جايزه هاى كوخٍتر فورى دارند تا جايزه هاى بزر تتر ولى ديرتر به طورى كه برخى ديكر از تحقيقـات نشـان دادهانـــ [9]]. مشاركت در فعاليت بدنى فرد را به جالش بيشترى كشـيده و ايـن

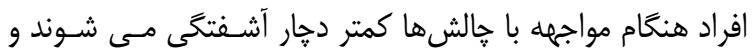
قادر خواهند بود هيجانات منفى خـود را كنتـرل كنتـد و بـه نحـو 


\section{تشكر وقدردانى}

اين مقاله براساس كار يزوهشى خانم حميده ديندار و فريبا ملائى

به راهنمايى خانم دكتر مهتا اسكندرنزاد در شهر تبريـز مس باشـد.

بدينوسيله نويسندكان از تمام كسانى كه در انجام اين يزوهش مارا

$$
\text { يارى نموده اند تشكر و قدردانى مى نمايند. }
$$

$$
\text { تفاوتهاى موجود بين دورههاى سنى و همجنين در نظـر حـرفتن }
$$$$
\text { عامل جنسيت سالمندان، انجام شوند. }
$$

\section{- References}

1. General Population and Housing Census. Iran Amar center: Management and Planning Iran. 2006. (persian).

2. Abdoli B. the study of elite athletes' personality. MA thesis. Tehran University. 1994. (persian).

3. Boyette L. Development of an exercise expert system for older adults. Journal of Rehabilitation Research and Development. 2006. 38: 1: 79-91.

4. Abdoli B, Shamsipour P, Shams A. Interactive role of personality traits and physical activity on mental and social development in the elderly. Salmand journal. 2009. 4:11: 7-15 (Persian).

5. Moeller FG, Barratt ES, Dougherty DM, Schmitz JM, Swann AC. Psychiatric aspects of impulsivity. American Journal of Psychiatry, 2001:158, 1783-1793.

6. Evenden, JA. Varieties of impulsivity. Psychopharmacology, 1999: 146, 348-361.

7. Ekhtiari H. Behzadi A., Jannati A., Moghimi A. Delayed Discounting Procedure and Impulsive Behaviors: A Preliminary Study, Advances in Cognitive Science, 2003, 5, 2, 4655.

8. Patton JH, Stanford M S, Barrat E S. Factor structure of the Barratt impulsiveness scale. Journal of Clinical Psychology, 1995;51, 768-774

9. Arce E \& Santisteban C. Impulsivity: A review. Psicothema, 2006:18, 213-220.

10. Costa PT, Terracciano A and McCrae RR. Gender differences in personality traits across cultures: robust and surprising findings. Journal of personality and social psychology, 2001; 81(2):322-331. 
11. Azimi N, Hasanvand S, Valizadeh M, Najmeh H. The relationship between the five factor model of personality with impulsivity, neuroticism and cognitive impulsivity, motor impulsivity and non-planning. The first conference on findings of cognitive science in education. 2011. (Persian).

12. Guilherme M, Lage L, Gallo G J, Cassiano IL, Lobo MV, Vieira JV, et al. Correlations between impulsivity and technical performance in handball female athletes. Psychology, 2011:2, 721-726

13. Pickering AD. The neuropsychology of impulsive antisocial sensation seeking personality traits: From dopamine to hippocampus function. In R. M. Stelmack (Ed.), on the psychobiology of personality: Essays in honor of Marvin Zuckerman. New York: Elsevier, 2004. 454-476.

14. Besharat M A, Ghahramani MH, Ahmadi N. [Athletics impulsively traits: A comparison between contact and noncontact sports]. Research in sport management and motor behavior, sport and motor science.2013. 11(5). 13-24. (Persian).

15. Kajtna T, Tusak M, Baric R, Burnik S. Personality in highrisk sports athletes. Kinesiology, 2004. 36, 1:24-34.

16. Kalkhoran FJ. Comparison between personality male and female athletes and nonathletes. Journal of Development \& Motor Learning. 2011. 8: 81-98. (Persian).

17. Fiho MGB, Ribeiro LCS, Garcia FG. Comparison of personality characteristics between high - level Brazilian athletes and non -athletes. Rev. Bras Med Esporte. 2005. 11 (2), 114118.

18. Hegbom F, Stavem K, Sire S, Heldal M, Orning OM, Gjesdal, K. Effect of short-term exercise training on sympthoms and quality of life elderly person. International journal of cardoilogy. 2007. 116: 272-284.

19. Trivedi SC, Shetty NK, Raut NB, Subramanyam AA, Shah HR, Pinto C. Study of suicidal ideations, hopelessness and impulsivity in elderly . J Geriatr Ment Health [serial online] 2014 [cited 2014 Oct 8 ];1:38-44

20. McCrae RR, Costa PT. Personality Development: Stability and change. Journal of Personality and Social Psychology. 2005; 3: 173-175.

21. Fathi Ashtiyani A, Dastani M. Psychological tests and mental health evaluation. 7th ed. Besat: 2010: 35-62. (Persian). 
22. Ekhtiari H, Rezvanfard M, Mokri A. Impulsivity and its Different Assessment Tools:A Review of View Points and Conducted Researches. Iranian Journal of Psychiatry and Clinical Psychology, 2008. 14, 3, 247-257. (Persian).

23. Aslankhani M, Farokhi A, Shamsipour Dehkordi P, Shams A, Ghasemian Moghaddam M. The relation of personality traits with depression severity in active and non-active elderly women in Tehran city. Salmand. 2010; 5 (2) :46-53

24. Kawachi I, Berkman, L. Social cohesion, social capital, and health. In L.Berkman \& I. Kawachi (Eds.), Social epidemiology. New York: Oxford University Press. . (2000).

25. McAuley E, Elavsky S, Motl RW, Konopack JF, Marquez DX. Physical activity, selfefficacy, and selfesteem: longitudinal relationships in older adults. Journal of Gerontology Behavior Psychology Science 2005; 60(5): 268-75.

26. Takahashi T, Oono H, Inoue T, Boku S, Kako Y, Kitaichi Y, et al. Depressive patients are more impulsive and inconsistent in intertemporal choice behavior for monetary gain and loss than healthy subjects--an analysis based on Tsallis' statistics. Neuro Endocrinol Lett 2008; $29: 351-8$

27. Dawe S, Loxton NJ. The role of Impulsivity in the development of substance use and eating disorders. Neuroscience and Biobehavioral reviews. 2004. 28(3)، 343-351.

28. Anami Alamdari H. Moslempour M, Hashemi T. The role of personality factors in the prediction of psychological capital. Iranian psychological association conference. 2010. 115117. (Persian).

29. Trivedi SC, Shetty NK, Raut NB, Subramanyam AA, Shah HR, Pinto C. Study of suicidal ideations, hopelessness and impulsivity in elderly . J Geriatr Ment Health. 2014; $1: 38-44$.

30. Abdoli B, Shamsipour, D P, Shams A. The Interactive Role of Physical Activity and Personality Traits inPsychosocial status of Elders. Salmand. 2009; 4(1) :93-109.

31. Badriazarin Y. Compare the quality of life in elderly athletes and non-athletes in Tabriz. Iranian Journal of Ageing. 2012; 8 (3):74-82. (Persian). 